\title{
Urban Services Growth in China: The Influence of Institutional Environment Factors
}

\author{
Yuan $\mathrm{Gao}^{1} \&$ Abdul Razak Chik ${ }^{2}$ \\ ${ }^{1}$ School of Economics, Hebei University, Baoding, China \\ ${ }^{2}$ School of Economics, Finance \& Banking, University Utara Malaysia, Kedah, Malaysia \\ Correspondence: Dr. Yuan Gao, School of Economics, Hebei University, No.180 Wusidong Road, Baoding 071000, \\ Hebei, China. Tel: 86-150-9740-1498. E-mail: michelle811@126.com
}

Received: May 25, 2015

doi:10.5430/rwe.v6n2p62
Accepted: June 10, 2015

Online Published: June 16, 2015

URL: http://dx.doi.org/10.5430/rwe.v6n2p62

\begin{abstract}
Urban services played increasing important role in China's economy. The economic marketization and internalization reform had greatly improved China's institutional environment, which contribute significantly to urban services growth. However, the effects of institutional environment factors on urban services growth are practically neglected. Therefore, to answer what are the institutional environment factors and how their effects on urban services growth in China, the paper selected urban services marketization and openness (FDI) level as institutional variables. Basing on data of 2009-2013 from 286 cities, the hierarchical multiple regression techniques was used to evaluate the effects of institutional factor. The findings indicated that both services marketization and openness level had significantly positive effects on urban services growth. In addition, it was found that a preferential policy was also important in services growth. This had policies implications that the government should implement strategies towards a more balanced urban services growth with specific priority on strategies to improve the urban services marketization and their openness level.
\end{abstract}

Keywords: urban services, institutional environments, services marketization, services openness

\section{Introduction}

Urban services growth is the natural process that plays an important role for urban and regional economies. Since urban area are places with developed economic growth, higher population density, better accessibility of infrastructures, abundant information and human resources, large number of economic organizations and complex economic relations, it provides a favorable environment for the development of services. Therefore, urban area are the natural spatial carrier for services (Hu, 2011; Chen et al., 2012).

However, despite the important strategic position of urban services in China, problems of apparent regional disparities have become major resistance for its growth. Urban services are well-developed in the Eastern regions, with the proportion of urban services output value to Eastern GDP of 62.0 percent in 2013, followed by Central region of 48.0 percent, while the underdeveloped Western regions falled behind with only 39.0 percent. In fact, the respective shares of regional GDP to national GDP revealed similar patterns, with 61 percent for Eastern region, 20 percent for Central region, and 19 percent for Western region respectively (China $\left.{ }_{1}, 2014\right)$. Therefore, the expanding regional gap in urban services does not only affect its own sustainable development, but also further enlarges the imbalance in regional economies $(\mathrm{Hu}, 2011)$.

With important role and obvious regional imbalance of services in China, some studies had been conducted to investigate factors influencing services growth, but mainly focused either on factor endowments of labor, capital, human capital (Hu, 2011; Wei, 2012; Zhang et al. 2012) or macroeconomic economic growth level (Ni, 2010; Cheng, 2011; Hu, 2011; Cheng \& Chen, et al. 2012). However, little attention had been attached specifically on institutional environment factors. In fact, China now is in its transition period, services growth is not only influenced by factor endowments and economic growth level, but also by institutional environment factors. A favorite institutional 
environment marked by the reduction of government intervention in economy, the deepening of marketiztation reform and services opening up to international market had generated great positive effects on China's services growth, since they provides an effective incentives and restraint mechanism for effective resource allocation and productivity improvement in services. (Hu, 2011)

In view of above, this paper posits that in the transition period of China, institutional environment factors have great influences on services growth. Accordingly, two issues concerning what are the institutional environment factors and how are their effects on services growth in China are generated in this paper.

\section{Urban Services in China}

The evolution of urban services growth in China can be divided into two distinct periods:

\subsection{Reform Periods: 1978-1992}

During economic reform and opening up from 1978 to 1992, China's economy was dominated by the high proportion of public ownership economy, and services were recognized as an useful supplement of national economy. Various low skilled individual service businesses such as catering, hair dressing, and repairing began to develop in urban areas. Since 1988, with the deepening of opening up policy and the increase in private capital accumulation, the private services enterprises were permitted to develop independently in urban areas (Liu, 2006). Several policies that encouraged services investment (Beijing, 1988 and 1990) were introduced by the government to encourage funds from Taiwan, Hong Kong, and Macau to invest in the services. Since then, the ownership structure in urban services had transformed from single public (or government) owned to multi-owned (including both public and private). However, urban services were still dominated by the traditional labor-intensive sectors, and were controlled by the government under the highly concentrated planned economy.

\subsection{Marketization Reform: Beyond 1992}

Urban services experienced rapid growth concurrent with industrialization since 1992, when the Chinese Economic Marketization Reform had been initiated. In 1992, the Central Committee and State Council of Chinese government introduced "The Decision on Accelerating Urban Services Development" (State Council of China, 1992) where the urban services were viewed as a strategic industry in urban and national economy. Since then, the government gradually relaxed the limitations on the business scope of private urban services. The private sectors and FDI were allowed to participate in services such as transportation, postal and telecommunication, and education services, which normally were under high government control. Meanwhile, due to rapid industrialization, various negative externalities began to emerge, such as the crowd traffics, scarce land, increasing rent especially for manufacturing enterprises, and severe pollutions by manufacturing enterprises. Subsequently, the government introduced a policy known as "Retreat Secondary Industry and Promote Service Industry in Urban" (State Council of China, 1995). The main focus of this policy was to upgrade the urban structure towards services. Thus, the secondary industry especially the polluted manufacturing industries should be gradually retreated from cities and transferred to suburbs. Under this policy, urban services experienced rapid growth.

As China joined WTO in 2001, various services sectors such as finance, construction, distribution, law, telecommunications, tourism, and transportation had been opened up to internal market. This initiative further propelled the growth of urban services. At the same time, the government accelerated the marketization reform to reduce government involvement, and encouraged multiple market participants in urban services. Hence, more than 3,000 laws, administrative regulations, and departmental rules were developed and amended, which had attracted the inflows of FDI in urban services and gradually formed a multiple ownership structure, implying the improvement in marketization level in urban services (Zheng, 2012). The government further emphasized strategies to accelerate urban services in "The Twelfth National Economic and Social Development Five-Year Plan" (2011-2015), marking the strategic positions of urban services.

As shown in Figure 1, the openness level in urban services experienced great improvement during 1990-2013. 


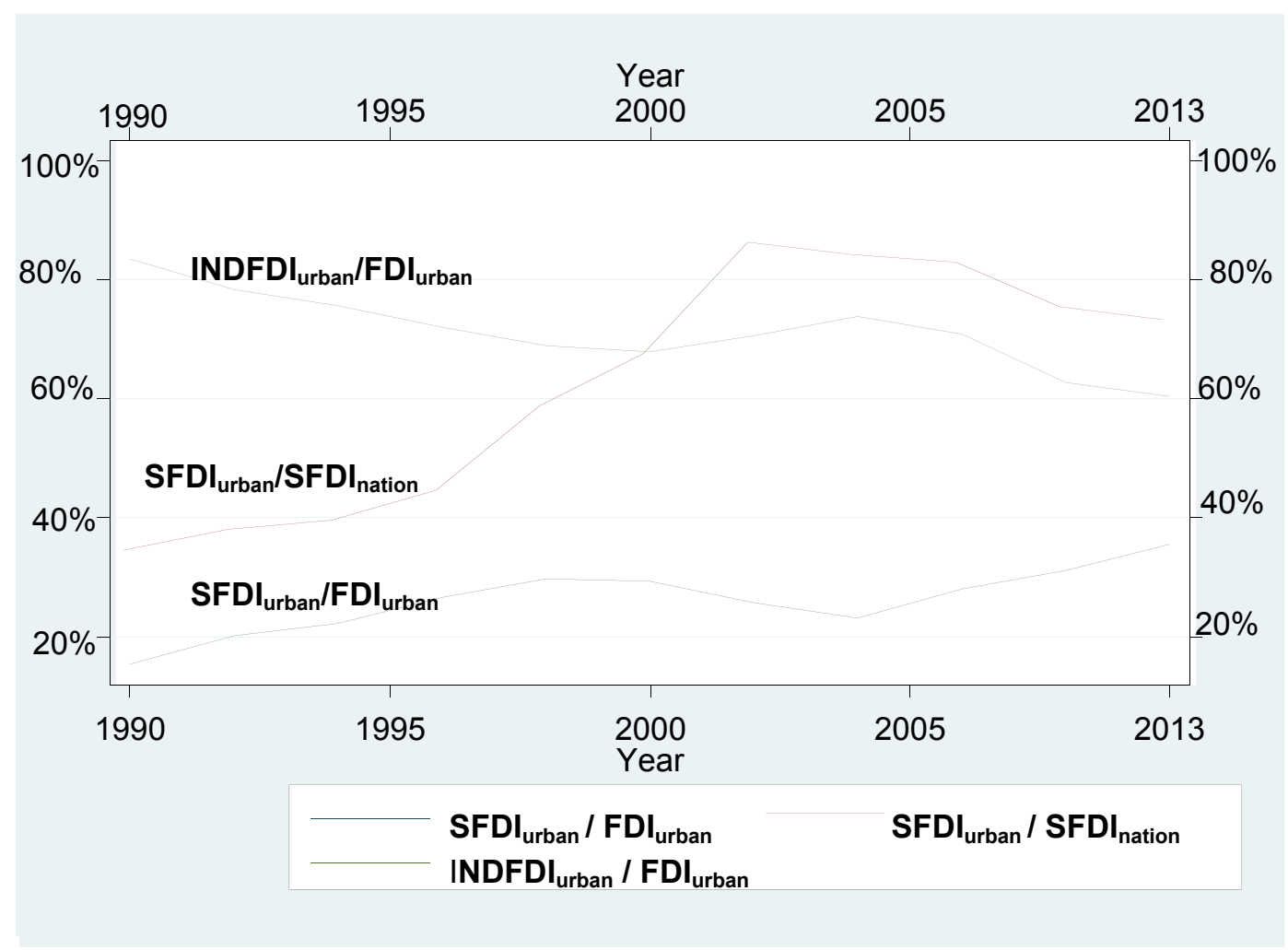

Figure 1. The proportion of FDI in urban services: 1990-2013

Source: China Urban Statistical Yearbook, 1991-2014

Figure 1 represents the share of FDI in urban services to national FDI in services $\left(\mathrm{SFDI}_{\text {urban }} / \mathrm{SFDI}_{\text {national }}\right)$ and the proportion of FDI in urban services to urban total FDI ( $\mathrm{SFDI}_{\text {urban }} / \mathrm{FDI}_{\text {urban }}$ ) respectively from 1990 to 2013 . The share of FDI in urban services to national FDI in services increased from 35.23 percent to 74.0 percent. This share increased to more than 80 percent since China's entrance to WTO in 2001. Despite of its share that decreased to 74.0 percent (since 2008) due to global finical crisis, urban services still absorbed the majority 70 percent of national FDI. Although the proportion of urban services' FDI to urban total FDI ( $\mathrm{SFDI}_{\text {urban }} / \mathrm{FDI}_{\text {urban }}$ ) increased from 15.4 percent to 35.6 percent, it still lagged behind that of the secondary industry (INDFDI ${ }_{\text {urban }} /$ FDI $_{\text {urban }}$ ), indicating at present, the urban secondary industry still dominates the FDI flows.

\section{Hypotheses Development}

This study identified two main institutional environment factors that influence urban services growth in China, namely services marketization and services openness.

\subsection{Services Marketization}

Marketization provides an effective incentive and mechanism for resources allocation in urban services that could promote services growth (Globerman and Shapiro2002; Benassy, 2005, Gwartnet, 2006; Hu, 2011; Wei et al., 2012). The improvement in services marketization level promotes the process of services separation, externalization, and outsourcing from manufacturing enterprises to outside market, and then develops into an independent industry through market mechanism (Chen, 2012).

Second, services marketization could accelerate the growth of nonstate-owned services and break the state monopoly, thus help to improve services productivity and structure (Fan, 2012). Great government intervention in urban services market activities would reduce the role of market mechanisms in resource allocation (Heckelman, 2000; $\mathrm{Hu}$ and $\mathrm{Ma}$ et al. 2012). In fact, if government participates too much in urban services, it is easier to bring rent-seeking and corruption activities, resulting in nonproductive consumption of large amounts of resources and increasing transaction costs of services that would hinder the growth of urban services (Wang, 2008; Yan and Wang et al., 2013). 
Urban services with a high marketization level (e.g., with a perfect financial and commercial market) would benefit urban services to gain adequate capital for their growth. In addition, the formation of market transaction order and equal market competition environment in urban services can attract the inflows of foreign capital that is conducive to urban services growth ( $\mathrm{Hu}, 2011 ; \mathrm{Hu}$ and $\mathrm{Ma}$ et al., 2012). Hence, the hypothesis is as follows:

\section{H1: Urban services growth is influenced by services marketization.}

\subsection{Services Openness}

Urban services openness refers to its degree to international market, which involves activities of international trade, international investment, and technological transfers on services. Urban services openness to international market has a positive effect on its growth. First, services opening-up through international trade, international finance, and foreign direct investment (FDI) would enlarge the market expansion effect. This will further deepen division of labour and specialization, and improve productivity in urban services, thereby contributing to urban services growth (Grossman and Helpman, 1991; Edwards, 1998; Stern et al., 2003). Second, the knowledge and technology spillovers effects through international trade and foreign direct investment are conducive to promote technological progress and productivity improvement, thus contributing to urban services growth. Third, urban services openness helps develop a competitive environment that encourages domestic services enterprises to innovate in order to improve services quality and productivity, and to improve the competitiveness of urban services (Stecher, 2005; Doucouliagos et al., 2006). In addition, the FDI in urban services are able to accelerate capital accumulation in host country, and effectively integrate various resources, which play an active role in promoting urban services' growth, such as broader market channels, advanced management, and core technology (Hu et al., 2011). Services openness would further improve services marketization level that is beneficial to urban services growth. Thus, the hypothesis is as follows:

\section{H2: Urban services growth is influenced by services openness.}

\section{Research Methodology}

\subsection{Sample and Data}

In order to test the effect of institutional environment on services growth in China, the 286 cities from 30 provinces of China (excluding Tibet, Hong Kong, Macao and Taiwan) are selected as research sample with time period of 2009-2013. In addition, in order to make a comparison between provinces, they are further divided into Eastern, Central and western regions. The data are collected from corresponding China Statistical Yearbook 2010-2014.

\subsection{Variables}

Rodrik (2002) and Tu (2012) constructed services growth model by directly focusing on institutional variables while neglecting other factors such as capital, labor and technology. They explained that although factor endowments were important in services growth, their effects could be realized only under a certain institutional arrangements. Therefore, in order to test hypothesis 1 and hypothesis 2, by reference to the method of Rodrik (2002) and Tu (2012), the paper select per capita urban services output value as dependent variable, while the two institutional variables of urban services marketization and openness (OPEN) level as independent variables. In addition, following $\mathrm{Hu}$ (2011), Huang (2011) and Li et al. (2012) the paper introduced dummy variable, namely: favorite policies on services (FP) and region (Area) to control their disturbances on services growth. They are explained in details as follows:

\subsubsection{Dependent Variable: Urban Services Growth}

Urban services growth can be measured either by services gross output value, output growth rate, or per capita output value (Hu, 2011). However, due to data avaialibity, this study adopted the total output value of urban services as a proxy for their growth level, as had been adopted by Huang (2011), Hu (2011), Guan (2012) and Wang et al. (2013). The values were then transformed into logarithm to avoid the heteroscedasticity (Hu, 2011; Guan, 2012; Wang et al., 2013).

\subsubsection{Independent Variables}

\section{1) Services Marketization}

The widely accepted measurement of Marketization level in China is the Marketization Index in NERI Year Report (Fan \& Wang, 2011). However, this index only calculates the marketization level at provincial level, without specific index at urban level. On the other hand, the China City Commercial Credit Environment Index (CEI, China 6 ) by Chinese Commercial Credit Research Centre reports the marketization level of commercial credit service sectors in cities at prefectural level, which could reflect the marketization level of urban services to a certain extent that is 
suitable as a proxy for urban services marketization level in this study.

The CEI is a comprehensive index, composing of seven first-level indicators and sixteen subindicators, ranging from 0 to 100 . The higher index value implies the higher marketization level of commercial services, thus indicating the higher marketization level of urban services.

\section{2) Services Openness}

FDI in urban services is considered as associated activities involving international trade, capital movement, and technological transfers on services. Thus, FDI in urban services has a comprehensive influence on services openness level ( $\mathrm{Li}, 2011 ; \mathrm{Hu}$, et al., 2011). Therefore, foreign direct investment in urban services is usually adopted as an indicator of services openness level (Huang, 2011; Hu et al., 2011). Following their method, the present study used the actual utilization amount of urban services' FDI as a proxy of its openness level.

\subsubsection{Dummy Variables}

\section{1) Favorite Polices (FP)}

It is notable that in China's transition period towards market economy, the government strengthened its macroeconomic management and institutional arrangements functions. Providing preferential regional policies is one of the significant performance of government macroeconomic management functions. The preferential economic or industrial policies to some region is conducive to attract the inflows of more resources in that region, thus would further promote the region's growth (Wei, 2012; Li et al., 2011). Especially, with the increasing role of services in China's economy in the post-industrialization period, the government begun to attach more attentions on implementing favorite polices towards services, hence it is also an important institutional indicator for services growth. Therefore, in order to control its influence, it is introduced as a dummy variable in the model. FP equals 1, if implement favorite policies on services, otherwise 0 .

\section{2) Area}

As discussed above, there existed great regional imbalance of urban services growth among the three economic region of China. Therefore, to control the disturbance of regional disparities, the paper grouped these 286 sample cities into Eastern, Central, and Western regions. Since the Western cities were most lagged compared to Eastern and Central regions, therefore, as had been carried out by Chen (2011), Zhang (2012), and Wang et al. (2013), the Western region would be used as a base dummy for comparison in this study. Thus,

Area $_{1}=1$ if eastern cities, otherwise 0 ;

Area $_{2}=1$ if central cities, otherwise 0 .

Therefore, basing on above discussions, we can get following equation:

$$
\text { LnURBS }=\alpha_{0}+\beta_{1} \text { MARK }+\beta_{2} \operatorname{lnOPEN}+\beta_{3} \mathrm{FP}+\beta_{4} \text { Area }+\varepsilon
$$

Where,

LnURBS: the natural logarithm of urban service growth

MARK: urban services marketization level

LnOPEN: natural log value of the amount of urban services FDI

FP: dummy variable favorite policies on services, $\mathrm{FP}=1$, if implement favorite policies on services, otherwise 0 .

Area $_{\mathrm{i}}$ : dummy variable, $\mathrm{Area}_{1}=1$ if Eastern cities, otherwise $0 ; \mathrm{Area}_{2}=1$ if Central cities, otherwise 0.

$\varepsilon:$ the random error term

\section{Regression Analysis and Findings}

This paper used hierarchical regression estimation technique to compute the significance and influence of each institutional factors on urban services growth by steps. The influence could be measured by assessing the value of R-square change when each variable was added into the model (Hair et al., 2006). Regression analysis start with descriptive statistics of the variables in regression model, then the regression estimation have been conducted to test the associations between the institutional factors (independent variables) and urban services growth (dependent variable ).

\subsection{Descriptive Statistics of Variables}

In order to view the real characteristics of variables, data for descriptive analysis were actual values before 
transformation. As the samples were 286 cities in China with 5-year period (2006-2010), the related variables were pool data (combined for all the five years) with a total 1,430 observations $(\mathrm{N}=286 \times 5)$. For comparison, the descriptive analysis was based on two steps: 1) All observations were categorized into two groups: a) high performance cities with corresponding variable's value above (or equal) the overall mean, and b) low performance cities with variable's value below the overall mean. 2) The distribution of the high performance variables within cities.

\subsubsection{Urban Services}

Table 1 presents the descriptive results of dependent variable namely urban services growth (URBS). From the total 1430 observations, its overall mean was RMB28.64 billion, with the substantial range from RMB0.72 billion to RMB 1,050 billion.

Table 1. Descriptive result of urban services during 2009-2013

\begin{tabular}{lcccccc}
\hline Variable & Frequency & Percentage & Mean & Min & Max & Std. Deviation \\
\hline URBS (RMB billion ) & & & & & & \\
$\quad$ Overall & $\mathbf{1 4 3 0}$ & $\mathbf{1 0 0 \%}$ & $\mathbf{2 8 . 6 4}$ & $\mathbf{0 . 7 2}$ & $\mathbf{1 0 5 0}$ & $\mathbf{7 . 8 5 8}$ \\
High performance ( $\geq$ overall mean ) & 261 & $18.2 \%$ & 119 & 288.9 & 1050 & 15.271 \\
Low performance (< overall mean ) & 1169 & $81.8 \%$ & 8.18 & 0.72 & 28.6 & 7.768 \\
\hline
\end{tabular}

As shown in Table1,based on the overall average performance, it is known that 18.2 percent cities had a high performance in urban services growth, with the mean value of RMB119 billion, i.e., RMB90.36 billion higher than the overall average value (RMB28.64 billion). However, the majority 81.8 percent cities had a low performance in urban services with the mean value of RMB8.18 billion, and by average was RMB20.46 billion lower than overall mean. This finding suggests that, the majority cities in China had a low performance in urban services growth.

Figure 2 further display the regional distributions of high performance urban services (above overall mean) among Eastern, Central, and Western cities.

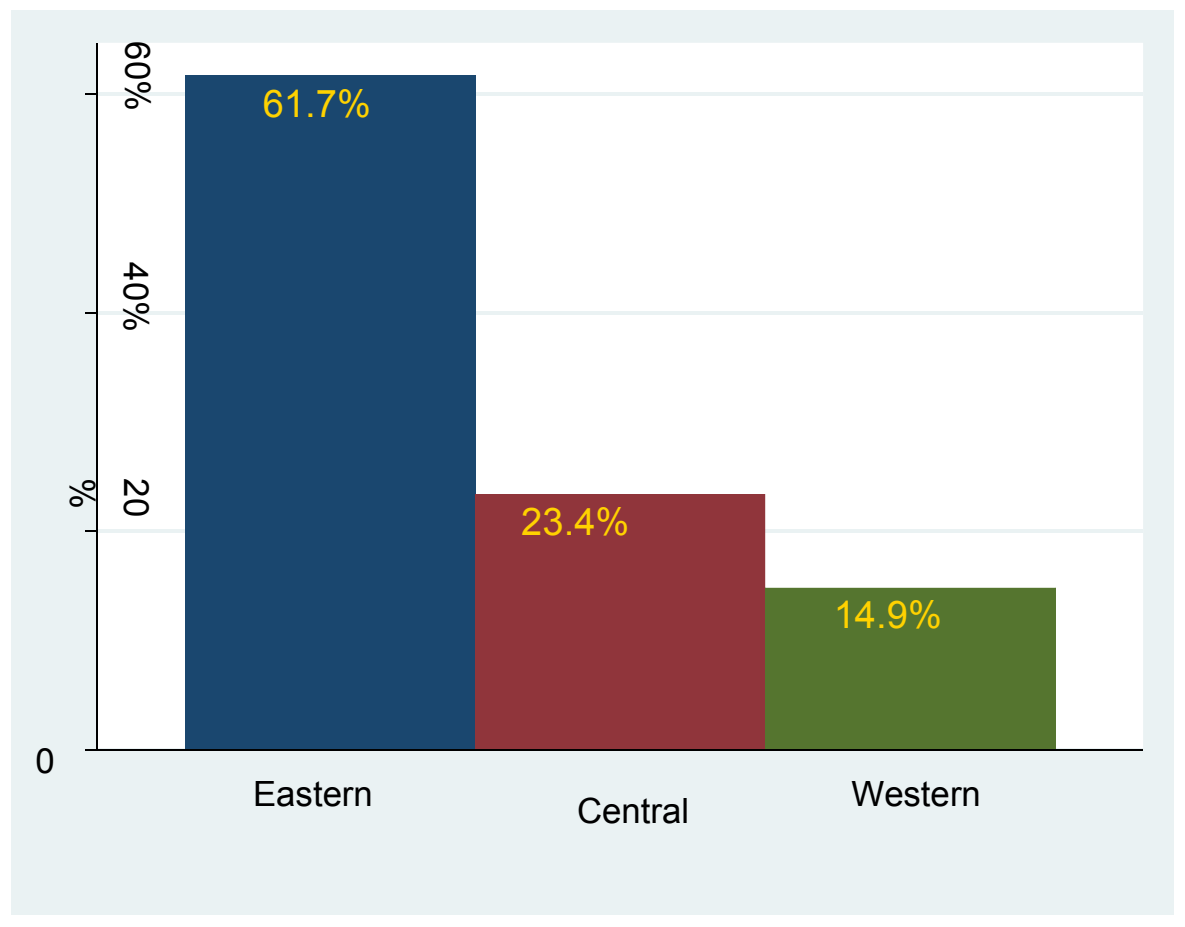

Figure 2. Regional distribution of high performance urban services 
From the 261 observations with high performance for urban services, 61.7 percent were from Eastern cities, 23.4 percent from Central cities, and the lowest 14.9 percent was from Western cities. This indirectly revealed substantial regional variations and gaps for urban services growth among cities in China.

\subsubsection{Institutional Factors}

Table 2 shows the descriptive results of institutional factors

Table 2. Descriptive results of institutional factors

\begin{tabular}{lcccccc}
\hline Variables & Frequency Percent & Mean & Min & Max & $\begin{array}{l}\text { Std. } \\
\text { Deviaton }\end{array}$ \\
\hline Marktization & $\mathbf{1 4 2 8}^{*}$ & $\mathbf{1 0 0 \%}$ & $\mathbf{6 0 . 6 5}$ & $\mathbf{3 7 . 9}$ & & \\
$\begin{array}{l}\text { Overall } \\
\text { high performance ( } \geq \text { overall mean }\end{array}$ & 705 & $49.4 \%$ & 68.61 & 60.67 & $\mathbf{8 6 . 6 0}$ & $\mathbf{9 . 5 7}$ \\
low performance (< overall mean) & & $50.6 \%$ & 52.89 & 37.9 & 86.60 & 4.64 \\
$\begin{array}{l}\text { Openness (RMB million) } \\
\text { overall }\end{array}$ & & & & & 60.62 & 6.18 \\
high performance ( $\geq$ overall mean & $\mathbf{1 2 8 2 *}$ & $\mathbf{1 0 0 \%}$ & $\mathbf{3 6 9 . 4 8}$ & $\mathbf{0 . 0 2}$ & $\mathbf{1 1 1 2 1 . 4 3}$ & $\mathbf{1 0 . 2 2}$ \\
low performance (< overall mean) & 1058 & $82.5 \%$ & 255.91 & 0.02 & 3662.20 & 15.91 \\
\hline
\end{tabular}

Note: * some missing data of the variable due to unavailability

It is known that, among the observations, $49.4 \%$ cities had high performance in marketization level, however, only $17.5 \%$ cities had high performance in services openness level. Furthermore, Figure 3 show the distribution of high performance institutional factors (above the overall mean values) among cities in the Eastern, Central, and Western regions.

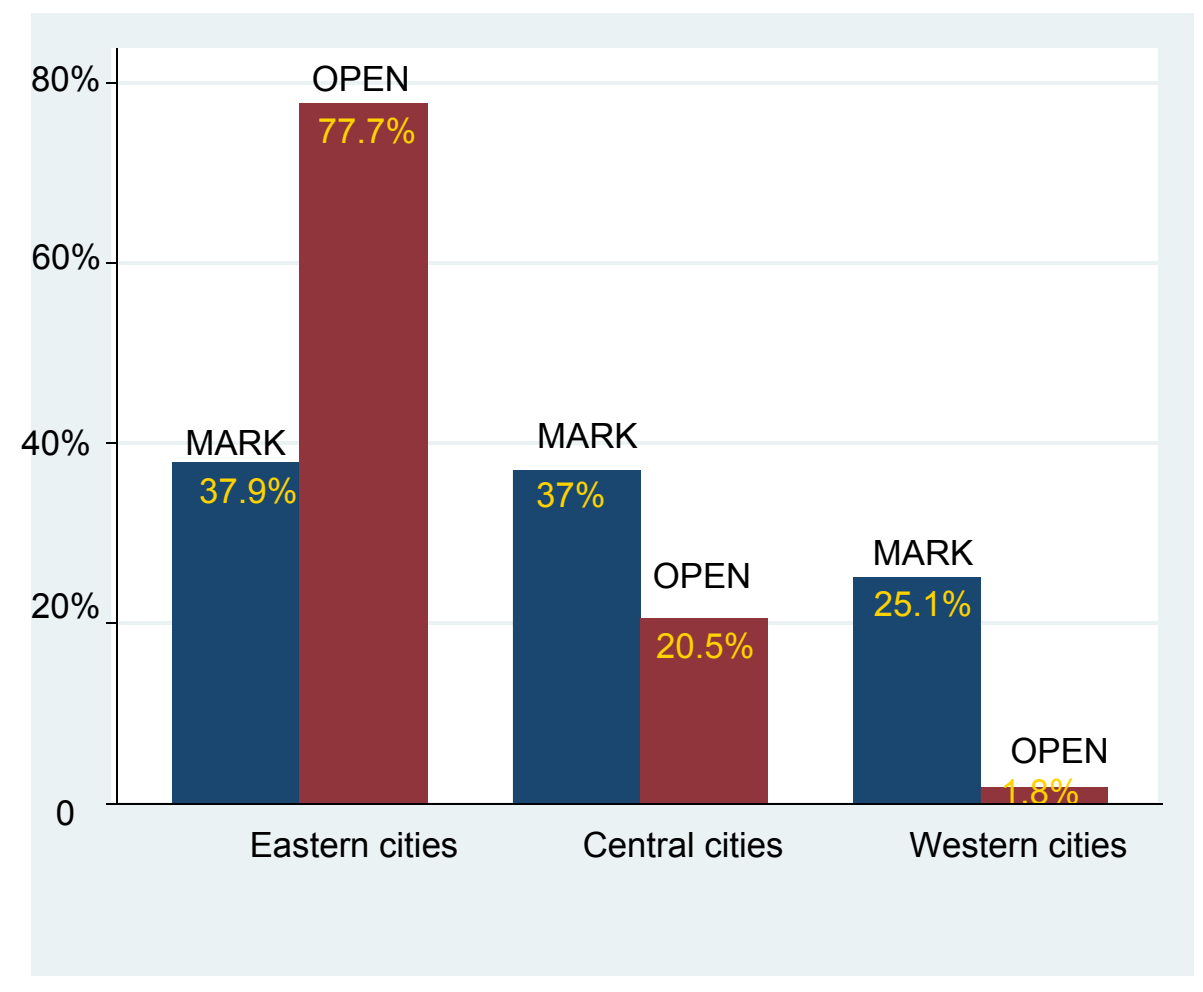

Figure 3. High performance: institutional factors 
As shown in Figure 3 the regional distribution of institutional factors showed that a 37.9 percent of the cities in Eastern region and 37 percent in Central region had a high services marketization level compared to cities in the Western region (25.1 percent). However, services openness showed substantial variations among the regions. An extremely high 77.7 percent was from Eastern cities, followed by 20.5 percent from Central cities, while only 1.8 percent was from Western cities. These results indicated great imbalance of institutional environment, especially services openness (FDI) among regions, implying that cities in Eastern region had absolute advantage in institutional factors compared to lagged cities in the Western region, due to regional disparities in economic development level, accessibility, infrastructures, auxiliary industries, preferential polices, and historical factors (Wei et al., 2012).

\subsection{Regression Estimations}

The effects of institutional environments factors on urban services growth were examined through hierarchical multiple regression of Model 1 until Model 3, respectively. In order to avoid possible heteroscedasticity problem, the Heteroskedasticity Consistent Standard Error Estimation (Robust estimations) was used on the following regression estimations to ensure the accuracy of results. In addition, there are no serious multicollinearity problems, since the VIF values for all the variables were far less than 10 (see Table 3).

Table 3. Summary of regression estimations

\begin{tabular}{lllllll}
\hline Variables & \multicolumn{2}{l}{ Result(1) National } & Result(2) Eastern & & Result(3) Central \\
& $\begin{array}{l}\text { Robust } \\
\text { Coefficients }\end{array}$ & VIF & $\begin{array}{l}\text { Robust Coefficients } \\
\text { (t-stactistics) }\end{array}$ & VIF & $\begin{array}{l}\text { Robust Coefficients } \\
\text { (t-stactistics) }\end{array}$ & VIF \\
\hline Constant & $15.746^{* * *}$ & & $12.8016^{* * *}$ & & 8.674428 & \\
MARK & $0.821^{* * *}$ & 1.75 & $0.657^{* *}$ & 2.38 & $0.619^{* * *}$ & 2.28 \\
LnOPEN & & & $0.456^{* * *}$ & 1.73 & $0.429^{* * *}$ & 1.80 \\
FP & & & & & $0.079^{* * *}$ & 1.24 \\
Area1 & $0.935^{* * *}$ & 1.85 & $0.657^{* * *}$ & 1.98 & $0.344^{* * *}$ & 2.39 \\
Area2 & $0.759^{* * *}$ & 1.58 & $0.487^{* * *}$ & 1.73 & $0.236^{* * *}$ & 2.21 \\
& & & & & & \\
Adjusted R2 & 0.250 & & 0.612 & & 0.693 & \\
$\mathrm{R}^{2}$-change & 0.250 & & 0.362 & & 0.081 & \\
F-statistics & 154.65 & & 332.26 & & 363.76 & \\
Sig.F-statistics & 0.000 & & 0.0000 & & & \\
\hline
\end{tabular}

Generally, all the F-values of Model 1 until Model 3 (which explain the overall significance of models) were found to be significant at 1 percent level, as all the p-values of $F$-statistics were less than 0.01 (sig. $F=0.000$ ), indicating that Model 1 until Model 3 had high goodness of fit in predicting the relationship between institutional factors and urban services growth. Furthermore, the value of $\mathrm{R}^{2}$ increased from 0.250 in Model 1 to 0.693 in Model 3, indicating that more influencing factors were added into the models, the overall explanation between independent variables and dependent variable would improve. This finding further proved that the institutional factors indeed influenced urban services growth. Their specific contributions towards urban services were discussed in detail as follows.

H1 which concerned on the relationship between services marketization and urban services growth, were examined in Model 1. The estimated $\mathrm{R}^{2}$ was 0.250 , suggesting that 25.0 percent of the variation in urban services growth was explained by services marketization. The coefficient of urban services marketization was 0.821 and significant at 1 percent level, meaning, when holding other factors constant, for every 1 percent increase in services marketization level, there would be a 0.821 percent increase in urban services output growth, thus H1 was supported.

As for H2, which concerned the effect of urban services openness on urban services growth, were examined in Model 2. The estimated $\mathrm{R}^{2}$ was 0.612 , suggesting that 61.2 percent of the variation in urban services growth was together explained by urban services marketization and openness level. The results also showed that there was 0.362 (0.612-0.250) increase in $\mathrm{R}^{2}$ from Model 1 to Model 2. This finding implied that, while holding urban services marketization constant, the inclusion of services openness into Model 2 resulted in an additional 36.2 percent increase in urban service growth. This finding suggested that services openness contributed significantly to urban services growth. The robust coefficients in Model 2 revealed that when holding other constant, the coefficients of openness level (LnOPEN) was significantly positive (0.456). Thus, $\mathrm{H} 2$ was supported.

Model 3 further examined the effect of dummy variable favorite polices (FP) on urban services. It was found that 
when holding institutional factors constant, the inclusion of favorite polices(FP) into Model 3 resulted in a 0.081 percent (0.693-0.612) increase in $\mathrm{R}^{2}$ from Model 2 to Model 3. This finding implied that, while holding urban services marketization and openness constant, the favorite polices(FP) brought an additional 8.1 percent increase in urban service growth, with the significant coefficient of 0.079 , implying that favorite polices on urban services indeed contribute towards urban services growth.

In addition, the dummy variables of Area $a_{1}$ and $A_{r e a}$ also registered significant values at 1 percent level in all of Model 1 to Model 3, indicating that when holding the other variables constant, urban services in Eastern (Area ${ }_{1}$ ) and Central cities $\left(\mathrm{Area}_{2}\right)$ were higher compared to Western base cities. This finding further justified that the regional differences in institutional factors would influence the balanced growth of urban services in cities.

\section{Conclusions and Recommendations}

Stemming from findings of the paper, it implied that a favorable institutional environments, such as, high services marketization and openness level, a favorite services polices are essential determinants in promoting urban services growth in China. A high services' marketization level indicates that the factors are effectively allocated, thus helpings to improve factor productivity in urban services. A high services openness level indicates a high participation degree of services in international activities. This high level of services openness is beneficial to services growth through enlarged market effect and positive spillover effects. Therefore, to improve services marketization and openness level, the government should decrease its economic involvement on resources allocation and implement internalization strategy for services. However, it is obvious that there existed great regional disparities concerning the effects of institutional factors on urban services growth, with the most significant contributions in eastern region, followed by central region, while the lowest in lagged western region. Therefore, several measures should be taken to create a favorable institutional environment for services growth in China as follows:

First, the Chinese government should speed up the marketization reform in urban services to ensure a fair and efficient market environment on resources allocation. This includes measures to reduce market barriers for private services enterprises' participation, to improve the legal system to strengthen the protection of prosperity rights for services enterprises, and to strengthen the supervisions on government intervention in services activities.

Second, the government should further open urban services sectors to international market, such as finance, insurance, telecommunication, and public services. High services openness level is helpful to create a fair market competition environment, and thus attracting the inflows of FDI for urban services growth.

Third, due to the preferential policies on services are important in its growth, the government should shift their focus of the inclined preferential policies in eastern regions towards central and western regions to narrow regional gaps in services growth.

\section{References}

Benassy, Q.A., Coupet, M., \& Mayer, T. (2005). Institutional Determinants of Foreign Direct Investment. CEPII Working Documents, No 5. France: Research Center for International Prospectives and Information Studies.

Chen, K. (2012). Research on the Upgrading of Inner Structure of Service Sector in China. Beijing: Economic Science Press.

Cheng, D.Z., \& Chen, F.J. (2011). The Relative Intensity of China's Service Industry and Its Impact on Labor Productivity. Journal of Management World, 3, 77-84.

Cheng, D.Z., \& Chen, K. (2012). The Development Level, Structure and Effects of Producer Services in China- An International Comparative Analysis Basing on Input- Output Method. Journal of Economic Research, 1, 76-88.

China1. (2014). China Urban Year Book. Beijing: China Statistical Press.

China2. (2010-2014). China Urban Year Book. Beijing: China Statistical Press.

Djankov, S., \& Hoekan. (2000). Foreign Investment and Productivity Growth in Czech Enterprises. World Bank Economic Review, 14(1), 49-64. http://dx.doi.org./10.1093/wber/14.1.49

Doucouliagos, C., \& Mehmet, A.U. (2006). Economic Freedom and Economic Growth: Does Specification Make a Difference? European Journal of Political Economy, 22(1), 60-81.

Edwards, S. (1998). Openness, Productivity and Growth: What Do We Really Know? Journal of Economics, 108(3), 383-398. http://onlinelibrary.wiley.com/doi/10.1111/1468-0297.00293/

Fan, G., Wang, X.L., \& Zhu, H.P. (2012). The Chinese Market Index: Regional Market Relative Progress Report. Beijing: Economic Science Press.

Gao, Y., \& Abdul, R.C. (2013). A Multiple Regression Analysis on Influencing Factors of Urban Services Growth in 
China. International Journal of Technology and Investment, (4). http://dx.doi.org/10.4236/ti.2013.41B001

Globerman, S., \& Shapiro, D. (2002). Governance Infrastructure and U.S. Foreign Direct Investment. Journal of International Business Studies, 23(2), 217-252. http://dx.doi.org/10.1057/palgrave.jibs.8400001

Grossman, G., \& Helpman, E. (1991). Innovation and Growth in the Global Economy. Cambridge: MIT Press.

Guan, C.M. (2012). The Empirical Analysis of Financial Services Agglomeration on Regional Growth in Yangtze River Delta. Journal of Economic Research, 7, 14-21.

Gwartnet, J.D., Holcombe, R.G., \& Lawson, R.A. (2006). Institutions and The Impact of Investment on Growth. Journal of Kyklos, 59(2), 255-273. http://dx.doi.org/10.1111/j.1467-6435.2006.00327.x

Hair, J.F., Black, W.C., \& Tatham, R.L. (2006). Multivariate Data Analysis (6 ${ }^{\text {th }}$ ed.). New York: Prentice Hall.

Heckelman, J.C. (2000). Economic Freedom and Economic Growth: A Short-Run Causal Investigation. Journal of Applied Economics, 3(1), 71-91.

Hu, L.W., \& Ma, G.X. (2012). The Measurement of Public Services Marketization Level. Journal of Fiscal Research, 7, 36-47.

Hu, X. (2011). Institutional Factors and Services Growth in China. Finance and Trade Economics, 8, 43-55.

Huang, S.J. (2011). The Emprirical analysis on the Relationship between Services' FDI and Services' Growth in China. Journal of International Trade, (4),106-109.

Jiang, X.J., \& Li, H. (2012). Services and China's Economy: The Relevance and the Potential for Accelerating Development. Economic Research, 1, 4-15.

Kokko, A. (2006). Productivity Spillovers from Competition between Local Firms and Foreign Affiliates. Journal of International Development, (8).

Li, H. (2012). Research on Influencing Factors of Regional Services in China. Finance and Trade Economics, 7 , $13-21$.

Li, S.H. (2011). Institutional Environment and Industrial Evolution in China. China Industrial Economy, (6), 23-30.

Liu, Z.B. (2006). The Development of Modern Producer Service and Structural of Manufacturing Industries. Journal of NanJing University, 5, 36-44.

Ni, P.F. (2010). Urban Services Growth in China: Hypotheses and Testing. Journal of Finance and Trade Economics, 7, 7-11.

Stecher, B. (2005). An Investor's Perspective on The Investment Climate in Developing Countries. Investment Climate, Growth and Poverty. Washington, D.C.: World Bank, 21-23.

Stern, N. (2003). Investment Climate: Lessons and Challenges. Cario: The Egyptian Center for Economic Studies.

Tu, W.Q. (2012). Regional Economic Disparities and Convergence in China. China Social Sciences, 1, 72-84.

Wang, F. (2013). Influencing Factors of Foreign Direct Investment in China's Services. World Economy Research, 1, 41-53.

Wang, L.Y. (2008). The Empirical Research on the Effect of Marketization Degree on Regional Economic Growth-Basing on Panel Data Analysis. Journal of Reform of Economic System, 2, 133-136.

Wang, X.L., \& Fan, G. (2013). Institutional Changes and Influencing Factors of Regional Growth in China. Journal of Economic Research, 1, 33-44.

Wei, Z.L. (2012). The Impact of FDI on the Total Factor Productivity of China's Service Industry: Based on the Analysis of Stochastic Frontier Panel Data Model. Journal of XiaMen University, 20, 115-122.

Yan, T., \& Wang, W.T. (2013). Study on the Effect of Public Services Marketization Level on Its Productivity. Journal of Economic Research, 5, 23-29.

Yin, F. (2011). Influencing Factors of Foreign Direct Investment in China's Services. Journal of World Economy Research, 1, 41-53.

Zhang, Z.R. (2012). Human Capital and TFP of Producer Services in China. Journal of Forward Position in Economics, 8, 12-18.

Zhao, Y.J., \& Wu, J. (2013). FDI in Services: The Empirical Analysis on Capital Effect and Technological Spillover Effect in China. Journal of Economic Issues, 3, 41-48.

Zheng, J.C., \& Xia, Q. (2012). Services and Regional Competitiveness. Zhejiang: Zhejiang University Press. 